\title{
PROCEDEE DE ECOLOGIZARE A SISTEMELOR DE PROTECȚIE INTEGRATĂ A MĂRULUI ȘI A VIȚEI DE VIE
}

\author{
Voineac V., Odobescu V., Jalbă S., Voineac I. \\ IGFPP, Chișinău, Republica Moldova MD-2002.vvoineac@mail.ru
}

\begin{abstract}
The results of experiments obtained in 2015 in apple orchards and in 2017 in vineyards showed that pheromone methods of capturing and sterilizing males of natural populations of apple worm and grape moth, installation of sticky pheromone traps and treated with biorational sterilizer Admiral 10 EC (pyriproxyfen), in the amount of 10-20 traps/ha depending on the population density, reduce their damage to the level of PED, do not act negatively on entomophagous insects from families (Coccinellidae, Chrysopida) and Arahnidae, and reduce energy and financial costs to carry out protection measures at $30-40 \%$.
\end{abstract}

Key words: pheromone traps, sterilizers, entomophagous insects, harmful insects, bioelectricants, pathogens.

\section{Introducere}

Problemele de elaborare a bazelor ştiințifice pentru agricultura ecologică și durabilă, necesită elaborare a unor sisteme de protecţie integrată a culturilor agricole, care ar permite activizarea forţelor naturale de rezistenţă a biocenozelor şi ar reduce formarea rezistenţei speciilor de patogeni și reducerea populaţiilor insectelor dăunătoare la nivelul pragului economic de dăunare (PED), reducerea cheltuielilor energetice şi financiare pentru efectuarea măsurilor de combatere a acestora. Agricultura ecologizată prevede perfecţionarea sistemelor existente de protecţie a culturilor agricole și forestiere în direcția sporirii rezistenței plantelor la boli şi dăunători, care sporesc diversitatea insectelor entomofage și polinizatoare. Reducerea volumului presei pesticide în combaterea insectelor dăunătoare și agenților patogeni se atinge prin utilizarea insecticidelor biologice și bioraţionale (capcaneleferomonale, luminiscente, nutritive, acvatice - simple sau în complex cu substanțe lipiciose, sterilizatoare chimice sau bioraționale) ce permit reducerea cheltuielilor financiare și energetice la 30-40\% [1].

Scopul principal a cercetărilor noastre a fost elaborarea metodelor ecologic inofensive de combatere a insectelor dăunătoare și patogenilor culturii de măr prin utilizarea metodelor feromonale de combatere a dăunătorilor și sporirea rezistenței plantelor la patogeni prin tratarea cu bioelisitorii- Reglalg, Recol, Paurin față de agenții patogeni principali a culturii de măr- Venturia inaequalis Wint și Podosphera leucotricha Salm.

\section{Materiale și metodele de cercetare}

Obiectele de cercetare au fost: viermele merelor (Cydia pomonella L), viermele oriental (Grapholita molesta Busck), molia minieră (Cemiostoma scitella L) și capcanele feromonale prelucrate cu substanța sterilizatoare biorațională -Admiral 10 EC (s.a pyriproxyfen), bioelisitorii -Reglalg, Recol, Paurin, insectele prădătoare entomofage din familii (Coccinellidae, Chrysopida) și Arahnidae.

Experimentele pentru determinarea eficacităţii metodelor feromonale de capturare și sterilizare a masculilor dăunătorilor și estimarea eficacității bioelisitorilor- Reglalr, Recol, Paurin în sporirea rezistenței a plantelor la patogenii -Venturia inaequalis Wint și Podosphera leucotricha Salm au fost montate în anul 2015 la cultura mărului, livada SRL „AgroBrio” s. Bacioi zona de Centru, soiurile -Vagner prizovoe și Mantuaner, pe suprafata de 12 ha.

Estimarea eficacităţii măsurilor de protecţie chimică s-au efectuat după metode omologate în republică [3]. Iar estimarea eficacității metodelor de aplicare a substanțelor 
biologic active după metodele primite în laborator și Centru de testare și omologare produselor fitosanitare.

Capcanele feromonale pentru capturarea și sterilizarea acestor dăunători s-au instalat uniform pe ha din contul 10-20 capcane/ha la o distanţă 30x30m și 30x15m, la înălţime cuvenită $(2-2,5 \mathrm{~m})$. În toate variantele au fost amplasate cîte trei capcane feromonale lipicioase de control pentru aprecierea densității populațielor. Evidența capturilor în capcanele de control s-a efectuat odată în 5-7 zile până la finisarea populaţiilor. Pentru determinarea eficacității metodelor de combatere în variantele experimentale, variantele etalon gospodăresc și martor, după apariția primelor dăunări a fructelor și frunzelor s-a efectuat examinarea cîte 300 de fructe și 100 de frunze la toate variantele cu recalcularea la 100, pentru comparația cu PED.

În anul 2017 experimentele de combatere a moliei strugurilor Lobesia botrana prin capturarea și sterilizarea masculilor s-au efectuat pe plantaţile viticole a Colegiului de Vinificației și Viticulturii din s.Stăuceni, 4 ha, soiul Aligote. În dependența de densitatea populației a L.botrana capcanele s-au instalat din contul 9-20 capcane/ha după metodele omologate. Evidența capturilor la capcanele de control s-au efectuat odată în 5 zile. Plăcile tratate cu sterilizator Admiral 10EC sau schimbat odată la 10 zile. Eficacitatea biologică s-a determinat dupa comparația gradului de atac la 300 de struguri, la fiecare variant cu varianta etalon chimic și martor. Estimarea eficacității bioelisitirilor Reglalg-0,5L/ha, Reglalg2,0L/ha și Paurin -2,0L/ha în combaterea patogenilor Plasmopara viticola, Uncinula necator şi Botrytis cinerea sa efectuat după metodele omologate [2,4].

\section{Rezultate și discuții}

Estimarea comparativă a eficacității metodei de autosterilizare și de capturare a masculilor în masa, în controlul populațiilor C.pomonella, G.molesta și C.scitella. a determinat că amplasarea 10-20 capcane/ha tratate cu sterilizator Admiral 10EC a redus procentul fructelor atacate medie pe variante: variante experimentale - 13,3\%, variant etalon$23,6 \%$, și la martor- $92,6 \%$; și la frunze populate cu $C$. scitella pe generații respective - 1,0\%$2,0 \%$; și 3,0\%-4,3\% la etalon; $5,3 \%-7,0 \%$ la martor; cu eficacitatea biologică la variante experimentale- 85,3\% (20 capcane/ha şi 63,0\%-10 capcane /ha); la etalon respectiv pe generații- 74,5\% și 64,3\%. S-a constatat că metoda de autosterilizare în condiţiile anului 2015 nu a influențat asupra densității populațiilor entomofagilor (Coccinellidae, Chrysopidae, Syrphidae, Arahnida). Printre afidofagi în livada de măr predominau speciile: Coccinella septempunctata, Harmonia axyridis și Adalia bipunctata (Coleoptera: Coccinellidae); Chrysopa carnea și Ch. formosa (Neuroptera: Chrysopidae), larvele și imago de sirfide (Diptera: Syrphidae). Se întâlneau în cantități suficiente polifagii Forficula auricularia, F. tomis (Dermaptera: Forficulidae) și reprezentanți ai clasei Arachnida (Aranea). În varianta prelucrată cu preparatul natural Admiral 10 EC numărul prădătorilor a fost mai mare de 5-10 ori de cât în etalonul chimic.

Estimarea comparativă a eficacității bioelisitorilor la controlul impactului patogenilor ne a arătat că ei au diminuat răspândirea şi dezvoltarea patogenului Venturia inaequalis Wint la $14 \%-18 \%$, pe frunze și la $9,8 \%-18,7 \%$ pe fructe, $M$. fructigena pe fructe $-85,8 \%-88,5$, la varianta etalon $-87,4 \%$, bioelesitorii au sporit indexul clorofilei cu $10-22 \mathrm{mg} / \mathrm{cm}^{2}$, greutatea fructelor cu - 6-28g în comparație cu etalonul. Analiza economică a demonstrat că cheltuielile directe financiare pentru efectuarea măsurilor de capturare în masă și autosterilizare a masculilor moliei strugurilor este cu 30-40\% mai mici în comparație cu etalon chimic. A fost determinat, că gradul de dezvoltare a clasterosporiozei pe frunze în luna iulie au constituit 43,0-69.0\% şi gradul de răspândire - 94,0-100\%. La fructe primele simptome a 
clasterosporiozei a apărut în a doua jumătate a lunii iulie: gradul de dezvoltare în variantele tratate cu bioelisitori constituie $0,2-0,9 \%$ ce este la nivelul etalonului chimic $(0,9 \%)$ și mai mic decât la varianta martor $(2 \%) 1$.

Experimentele de estimare a eficacității metodelor de capturarea și autosterilizare a masculilor moliei strugurilor Lobesia botrana la vița de vie au fost efectuate în anul 2017 pe plantațiile viticole a Colegiului de Vinificației și Viticulturii din s.Stăuceni, soiul Aligote, au fost așezate 4 variante: V1- autosterilizare, V2 -capturarea în masă, V3-etalon chimic, V4martor netratat. S-a constatat că instalarea a 9 capcane ha, atît pentru capturare cît și pentru sterilizarea masculilor, pe fonul densității populației înalte (150-200 masculi/capcană/5zile) a redus atacul larvelor la struguri, respectiv pe generații la $4,3 \% ; 0,7 \% ; 1,6 \%$, iar la 20 capcane/ha la $3 \% ; 6 \% ; 1.0 \%$, în comparaţie cu etalon chimic $0.7 \% ; 4.0 \%$ și $5.6 \%$ la martor. La plantație de soiului Merlot cu densitatea populației scăzută (40-70 msculi/capcană/5zile) gradul de atac a larvelor a atins pe variante: 20 capcana/ha tratate cu Admiral - 1.0\%; 1.3\% ; $1.3 \%$; la varianta cu 9 capcane/ha $-1.7 \% ; 1.7 \% ; 1.7 \%$; la etalon chimic $-2.3 \% ; 3.0 \% ; 3.0 \%$ și martor-5.3\%; $6.3 \% ; 6.7 \%$.

Eficacitatea biologică a metodelor de capturare și autosterilizare a masculilor L.botrana în capcanele feromonale pe plantațiile s.Stăuceni, soiul Aligote a constituit pe generaţii: 20 cap./ha $-74.8 \%$; 87.0\%;98.0\%; 9 cap./ha-34.9\%;0.0\%;0.0\%; la etalon-69.9\%; $90.0 \%$; 98.0\%; capturarea în masă- 9 capcane/ha- 30.0\%; 48.1\%; 33.3\%. Eficacitatea biologică a metodei de autosterilizare a masculilor L.botrana pe plantații scăzute s.Ciorescu a fost pe generaţii: la varianta 20 cap./ha $-81.1 \%$; 79.3\%; n80.5\%; 9cap../ha - 67.9\%;73.0 ;74.7\%; etalon- 56.6\%; 52.3\%; 55.2\%; capturarea în masă 9 cap/ha- 56.6\%; 52.3\%; 55.2\%.

Eficacitatea biologică a bioelisitorilor Reglalg, Recol și Paurin în combaterea Plasmopara viticola la vița de vie pe struguri, în 2017 ( datele rap. D. Elisovețchii) a atins în lunile: iulie- $96.6 \%-98.3 \%$, august- $84.2 \%-89.1 \%$ și septembrie $-78.7 \%-82.9 \%$, pe cînd la varianta etalonul chimic ea a fost de - 89.3\%; 80.8; 73,7\%. Eficacitatea biologică a bioelisitorilor în combaterea Uncinula necator pe struguri a atins- 98.3\% în iulie, 89.5-91.9\% în august și 87.5-90.1 \% în septembrie, la etalonul chimic ea a constituit - 86.7\%; 87.3\%; $84.6 \%$ respectiv. Tratamentele preventive cu bioelisitorii- Reglalg, Recol și Paurin a permis complet suprimarea dezvoltării bolii Botrytis cinerea pe struguri în condițiile anului 2017.

\section{Concluzii:}

1. Instalarea capcanelor feromonale a Cydia pomonella, Grapholita molesta, Cemiostoma scitella în livada de măr, în dependența de densitatea populațiilor, în cantitatea de 10 - 20 capcane/ha permite de a reduce procentul fructelor dăunate la nivelul PED (pragul economic de daună).

2. Plăcile prelucrate cu sterilizatorul Admiral 10 EC trebuie schimbate peste 10 zile, sau a doua zi după ploaie abundentă.

3. În condițile climaterice a anului 2015 la densitatea populațiilor înalte de viermele merelor și oriental, reducerea gradului de atac a fructelor a atins la variantele cu instalarea 10 capcane/ha a redus gradul de atac la fructe la 13,3\%, și atacului moliei la frunze la 1,0\%$2,0 \%$, cu eficacitatea biologică contra viermelor de $63,0 \%-85,3 \%$ și contra moliei de $50.0 \%$.

4. Estimarea comparativă a eficacității bioelisitorilor în controlul impactului patogenilor ne-a arătat că trei tratamente a pomilor de măr cu bioelisitorii au diminuat răspândirea și dezvoltarea patogenului Venturia inaequalis la 14\%-18\% pe frunze și la 9,8\% $18,7 \%$ pe fructe, și a patogenului $M$. fructigena pe fructe $-85,8 \%-88,5 \%$ în comparație cu$87,4 \%$ la varianta etalon. 
5. În combaterea moliei strugurilor cu populațiile înalte de Lobesia botrana instalarea a 9 capcane/ha reduce gradul de atac la strugurilor la 4,3\%; $0,7 \% ; 1,6 \%$, iar la 20 capcane/ha la $3 \% ; 6 \% ; 1.0 \%$, cu eficacitatea respectivă: 9 cap./ha-34.9\%;0.0\%;0.0\%; 20cap./ha $-74.8 \%$; $87.0 \% ; 98.0 \%$ și la etalon- $69.9 \%$; 90.0\%; 98.0\%; la capturarea în masă- 9 capcane/ha$30.0 \% ; 48.1 \% ; 33.3 \%$.

6. Eficacitatea biologică a trei tratamente cu bioelisitori Reglalg, Recol și Paurin în combaterea Plasmopara viticola la vița de vie pe struguri, în 2017 (datele rap. D. Elisovețchii) a atins în lunile: iulie- $96.6 \%-98.3 \%$, august- $84.2 \%-89.1 \%$ şi septembrie $-78.7 \%-82.9 \%$, pe cînd la varianta etalonul chimic ea a fost de $-89.3 \% ; 80.8 ; 73,7 \%$. Iar eficacitatea biologică a lor în combaterea Uncinula necator pe struguri a atins- 98.3\% în iulie, 89.5-91.9\% în august și $87.5-90.1 \%$ în septembrie, la etalonul chimic ea a constituit $-86.7 \% ; 87.3 \%$; $84.6 \%$ respectiv.

7. Atît capturarea în masă cît și sterilizarea masculilor dăunătorilor principali la ambele culturi nu influențează negativ la numărul insectelor entomofage.

\section{Bibliografie}

1.Войняк В.И. и др. Методические рекомендации по применению синтетических половых феромонов гроздевой и двулётной листоверток в интегрированной системе защиты виноградной лозы. Москва, 1986.

2.Войняк В.И. и др. Итоги и персктивы применения БАВ в системах интегрированной защиты растений. „Protecţia Plantelor - Realizări şi Perspective”. Информационный бюллетень ВПРС МООБ, 40, Кишинёв, 2009, с. 212-217.

3.Временные методические указания по выявлению и учету численности вредных и полезных организмов, болезней с/х культур. Кишинев, 1988, 68c.

4.Рябчинская Т.А. и др. Природные лиганды и перспективы их практического использования в фитосанитарных технологиях. Агрохимия. 2012, 11, 34-39.

5.Сазонов А.П. и др. Рекомендация по практическому применению БАВ в интегрированной системе защиты плодовых культур от вредителей. М: 1986.30 с. 